TITLE:

\title{
Access to government information in Japan: a long way toward electronic government?
}

$\operatorname{AUTHOR}(\mathrm{S}):$

Koga, Takashi

\section{CITATION:}

Koga, Takashi. Access to government information in Japan: a long way toward electronic government?. Government Information Quarterly 2003, 20(1): 47-62

\section{ISSUE DATE:}

2003-02-23

URL:

http://hdl.handle.net/2433/93004

\section{RIGHT:}

Copyright: (c) 2003 Elsevier Science Inc. All rights reserved.; This is not the published version. Please cite only the published version.; この論文 は出版社版でありません。引用の際には出版社版をご確認ご利用くだ さい。 
Access to Government Information in Japan: A Long Way toward Electronic Government?

Takashi Koga

Doctoral Student, Laboratory of Library and Information Science, Graduate School of Education, University of Tokyo, 7-3-1 Hongo, Bunkyo-ku, Tokyo 113-0033, Japan

Tel.: +81-3-5841-3976; fax: +81-3-5841-3917.

E-mail address:pp97028@mail.ecc.u-tokyo.ac.jp (T. Koga).

\section{About the Author}

Takashi Koga is a doctoral student of the Laboratory of Library and Information Science, Graduate School of Education, University of Tokyo, Japan. He has received a B.A. in Law and a M.A. in Education from the University of Tokyo, and a MLS from Syracuse University, USA. Koga is a winner of young author best paper awards of the Japan Society of Library and Information Science and of the Records Management Society of Japan, for his articles about the Federal Depository Library Program and information resources management policy in the United States, respectively. 
Access to Government Information in Japan: A Long Way toward Electronic Government?

\begin{abstract}
Supported by the development of information technology, the Japanese government is facilitating access to its information and taking steps toward electronic government. The policy initiatives concerning access to government information are divided into five areas: promotion of IT use in internal administrative activities, the Information Disclosure Law, information provision, record management, and general policy toward information society. However, these policy initiatives do not reflect the needs of the citizen, and implementation of the policy is curtailed by the lack of leadership and coordination. In addition, the government still holds a monopoly over its information and has poor control over flow and storage of government information.
\end{abstract}


Access to Government Information in Japan

Access to Government Information in Japan: A Long Way toward Electronic Government?

\section{Introduction}

Electronic government can be defined as a government's "use of technology, particularly web-based Internet applications, to enhance the access to and delivery of government information and service to citizens, business partners, employees, other agencies, and entities." ${ }^{1}$ According to the "four stages of a growth model e-government" by Layne and Lee ${ }^{2}$, Japanese government is still situated at the first stage: “cataloging," i.e. on-line presentations of government information and forms, which are organized by services, different actions, and different events. Only a few government agencies, especially those concerning business regulations, step into the second stage: online service delivery with direct online transactions between the government and the citizens / businesses. The Japanese government is still far from realizing the third stage, vertical integration across different levels of the government within similar functionality, and the forth stage, horizontal integration across different functions and services.

Actually, it is a significant movement for the Japanese government to arrive at the "cataloging" stage of electronic government because the Japanese government had shown a primary concern for protecting the security of the state and a very lackluster attitude toward openness of government information for a long time. Such an attitude has changed gradually during this decade, toward a more open system of public access within a broader context of electronic government. This transition has been laid out in a 
series of policy plans beginning with the "Master Plan for Promoting Government-Wide Use of Information Technology" in 1994, and coming to fruition in a series of guidelines recently published to supplement the landmark Information Disclosure Law (IDL) passed in 1999. While these policy initiatives have opened up the way to electronic government, the Japanese government seems to struggle bitterly against several barriers preventing full realization of providing on-line government information and forms. If the Japanese government wants to proceed to advanced stages of electronic government, it will need to overcome barriers in the first, basic but important stage for electronic government.

This article focuses on the aspects concerning provision of, and access to, government information relating to electronic government in Japan. First, it reviews policy initiatives concerning electronic provision of government information and the wider issue of electronic government. Such policy initiatives include those concerning the information infrastructure, information provision, information disclosure (the IDL), record management, and the general policy for information society. Then, it analyzes these policy initiatives and points out problems concerning the implementation of these initiatives. Finally, it provides a recommendation for better access to government information in Japan.

This article primarily focuses on information provision activities of the administrative sector of the central government, because this sector is most influenced by the policy initiatives for electronic government. Therefore, this article does not deal with policy initiatives for electronic government in the legislative or judicial sector, nor the initiatives in local governments. ${ }^{3}$ 


\section{Policies Concerning Administrative Information Provision}

\subsection{Master Plan for Promoting Government-Wide Use of Information Technology}

The series of policies that began with the "Master Plan for Promoting Government-Wide Use of Information Technology" have clarified the framework for the basis of electronic government in Japan. This "Master Plan" was adopted by the Cabinet on December 25, 1994, and revised on December 20, 1997. ${ }^{4}$ The revision shows the shift of policy focus on "Government-Wide Use of Information Technology" from internal efficiency to external responsiveness. As later discussion shows, this "Master Plan" has been incorporated into a wider policy for "information society in Japan."

The original "Master Plan" of 1994 was mainly concerned with the development of information infrastructure; though this plan did not use the word "Internet," it mandated government ministries to develop intra-ministerial LAN and inter-ministerial WAN (Wide Area Network). However, the aim of such information infrastructure was for promotion of internal efficiency of administrative activities by the use of the infrastructure. The original "Master Plan" mentioned "utilization of administrative information for the society" and "development of an administrative information clearing system,” though such issues were not described in detail.

As discussed below, after the adoption of the original "Master Plan" in 1994, the discussion over the IDL plan urged not only disclosure of administrative records by requests, but also proactive provision of administrative information. In addition, by the end of 1997, the development of the information infrastructure for internal 
administrative use rapidly advanced (inter-ministerial WAN was launched in January 1997), while the Internet was recognized as a new communication infrastructure in Japanese society. These issues led to the revision of the "Master Plan" in December 1997.

In the revised "Master Plan" of 1997, Japanese government used the word "electronic government" for the first time; "Targets" of the revised "Master Plan" said, "The government shall ... aim at realizing highly advanced electronic public administration, or "Electronic Government," at the beginning of the twenty-first century." Also, the revised "Master Plan" provided the "Fundamental Policies for Promoting Government-Wide Use of IT", which gave examples of "Provision(s) of Government Information.” It included:

- Timely provision of government information "such as press releases and other various types of information necessary for people's lives" via Internet home pages,

- Promotion of providing government information "such as white papers and annual reports compiled to make current status of the public administration open to the public" via the Internet and CD-ROMs,

- Provision of "various information useful to the public" such as statistical data via electronic format, and standardization of this kind of data,

- Development and promotion of Geographical Information Systems (GIS), and

- Creation of "an integrated locator system and a locator system for each ministry," which would be available to the public by the end of FY1999, i.e. March 2000. (These locator systems were recognized as an equivalent to the "administrative information clearing system" in the original "Master Plan" of 
1994.)

In this way, the Revised Master Plan of 1997 provided a blueprint for the reform of administrative information provision.

\subsection{Enactment of the Information Disclosure Law and Its Effect}

The enactment of the Information Disclosure Law (IDL; Law No. 42 of 1999) in 1999 can be recognized as a catalyst for providing administrative information. That is, the discussion over the IDL plan from 1995 to 1996 led to the revision of the "Master Plan for Promoting Government-Wide Use of Information Technology" in 1997, which in turn led toward the promotion of administrative information provision. Also, policy guidelines concerning proactive information provision and record management followed the enactment of the IDL. In addition, the IDL ensures, albeit imperfectly, the transparency of government, which is necessary for citizens' trust in government and smooth and sound activities of electronic government.

\subsubsection{The Process toward the Enactment of the IDL}

This section reviews the process toward the enactment of the IDL briefly. ${ }^{5}$

Despite the cry for the IDL due to the grave political scandal in the Cabinet in the 1970's and the following movement among local governments to create their own information disclosure ordinances in the 1980's, the central government, led by the long-dominating Liberal Democratic Party (LDP), had shown little interest in the enactment of the national information disclosure law. The real discussion toward the IDL enactment began in the mid-1990's. This is due to the political change (temporary 
fall of the LDP from 1993 to 1994) and the domestic and international (especially from the United States) pressure for administrative reform, especially for transparent business regulations. Prior to the discussion over the IDL plan, these issues led to the enactment of the Administration Procedure Law (Law No. 88 of 1993) in November 1993, which promotes revealing government information concerning regulatory practices. ${ }^{6}$

The governing coalition of the LDP and other parties began discussions toward the enactment of the IDL by establishing the Administrative Reform Committee (ARC) as an independent advisory committee in November 1994. The agenda of the ARC included research and discussion about the IDL plan as well as reform of administrative activities such as business regulations. In March 1995, this committee launched an Administrative Information Disclosure Subcommittee. The next nineteen months of research, discussion, and feedback from outside sources included issues such as provision of administrative information and administrative records management. Following this subcommittee's proposal for an IDL in November 1996, the ARC submitted the proposed IDL to the Cabinet in December 1996.

After review and discussion over the proposal from the ARC, the government submitted the IDL bill to the Diet on March 27, 1998. There were a number of differences between the bill and the ARC proposal, including the omission of the term "right to know." The opposition parties also submitted their own bills including the "right to know" and pressured the government into making several concessions. Finally, on May 7, 1999, the Diet passed the IDL without the "right to know." The IDL came into effect on April 1, 2001.7 


\subsubsection{Disclosure of Government Records}

The main purpose of the IDL is to provide procedures for disclosure of administrative documents upon request. While the detailed analysis of the procedures is beyond the scope of this article, 8 it may be useful to point out some issues in the IDL concerning disclosure of administrative records in an electronic environment.

On the one hand, under the IDL, an administrative record in an electronic format is accessible; the definition of an "administrative document" as an object of disclosure includes an "electromagnetic record," that is, "a record created in a form that cannot be recognized through one's sense of perception such as in an electronic form or magnetic form." (Article 2, Section 2) As far as this definition is concerned, the IDL responds to the reality of administrative activities in the electronic environment. On the other hand, the IDL does not take full advantage of information technology. For example, Article 4, Section 1 of the IDL provides: "A request for disclosure ... shall be submitted to the head of an administrative organ as a document." This section is interpreted that the request must be done in person and that a request by FAX or e-mail cannot be accepted. Also, Article 9 of the Cabinet Order for the Enactment of the IDL (Cabinet Order No. 41, February 16, 2000) allows disclosure of electromagnetic records in paper, electronic tape or electronic disc format, though it does not allow the delivery of disclosed records via e-mail.

\subsubsection{Proactive Provision of Administrative Information}

In contrast with detailed procedures for disclosure of administrative records upon requests, the IDL provides basic and abstract policies for proactive provision of administrative information. After the enactment of the IDL, a supplementary guideline 
in 2001 provided more concrete policies for the proactive provision.

The IDL "Article 40: Enhancement of Measures for the Provision of Information Held by Administrative Organs" says:

In order to comprehensively promote disclosure of the information it holds, the government shall strive to enhance measures concerned with the provision of information held by administrative organs, making clear to the people through timely as well as appropriate methods the information that administrative organs hold.

Based on this provision of the IDL, and as a continuation of the revised "Master Plan for Promoting Government-Wide Use of Information Technology" of 1997, the "Basic Plan for Electronic Provision of Administrative Information" was approved by the Inter-Ministerial Council for Promoting Government-Wide Use of Information Technology on March 29, 2001. This plan specifies the objects of electronic provision as follows:

(1) Information about administrative activities,

(2) Information for effective use in society,

(3) Information about which laws and regulations mandate provision, and

(4) Information that will be requested frequently through IDL procedure.

This basic plan also shows standardized categories under which each ministry and agency shall provide its information on the Web, as shown in Table 1. In this way, the government is promoting provision of administrative information via the Internet.

[Table 1 about here.] 


\subsubsection{Record Management}

Another issue that supports access to administrative information is record management. The discussion over the IDL plan recognized that a proper record management system would lead to smooth disclosure of requested administrative records. In fact, there had been no legislation for administrative record management until the IDL. Guidelines concerning record management were supplemented to the basic and abstract policies in the IDL, which helped address the issue of proactive provision of administrative information.

"Article 37: Management of Administrative Documents" of the IDL states that "Rules for the proper management of administrative documents shall be established as provided for by Cabinet Order, and they shall be made available for public inspection." 9 Following this article, the government issued several regulations concerning record management:

- Cabinet Order for the Enactment of the IDL (Cabinet Order No. 41, February 16, 2000): Article 16 of the order provides details about record management. In particular, it mandates each administrative organ maintain inventories for administrative record files in electronic disk format.

- Guidelines for the management of administrative records (agreed by the Inter-Ministerial Council for Internal Business on February 25, 2000): These guidelines provide detailed policies and procedures for creation, classification, maintenance, replacement, disposal, and other management issues of administrative records. It also specifies details of "inventories for administrative record files," described in the above Cabinet Order, as "databases that are accessible via the intra-ministerial LAN and 


\section{inter-ministerial WAN.”}

- Memorandum for the development of a record management system (approved by the Inter-Ministerial Council for Internal Business and by the Board of Directors of the Inter-Ministerial Council for Administrative Information System on March 29, 2000): This memorandum mandates the ministries to create an "inter-ministerial record file management system" and an "intra-ministerial record management system" based on the inventories described above, and to provide access to both systems to the public via the Internet.

\subsection{Policy Initiatives toward Electronic Government in a Wider Context}

It should be noted that policy initiatives for administrative information provision and electronic government have been recognized as part of the whole picture of an "information society" in Japan during recent years.

In 1994, the Japanese government established the Advanced Information and Telecommunication Society Promotion Headquarters as an advisory committee for the Cabinet, and the Headquarters issued "A Basic Plan for Promotion of Advanced Information and a Telecommunication Society" on February 21, 1995. This plan included a policy agenda for improvement of public sector activities, though it simply followed the original "Master Plan for Promoting Government-Wide Use of Information Technology" in 1994. While the plan of 1995 also provided a policy agenda in other areas such as the development of information infrastructure, information security and copyright, the plan lacked a holistic approach to the development of an "information 
society."

After the "Basic Plan" of 1995, while the Advanced Information and Telecommunication Society Promotion Headquarters continued its activities in policy-making for an information society in Japan, the government recognized that a more comprehensive plan, taking advantage of information technology, would be necessary to catch up with other nations promoting electronic government. Therefore, the central government reorganized the Advanced Information and Telecommunication Society Promotion Headquarters into the IT Strategy Headquarters in July 2000. Then, based on the Basic Law on the Formation of an Advanced Information and Telecommunications Network Society, ${ }^{10}$ which was enacted on November 29, 2000, the new Headquarters issued the e-Japan Strategy ${ }^{11}$ on January 22, 2001. The e-Japan Strategy is a strategic framework for the development of Japan's information society and outlines the government's commitment to becoming "the world's most advanced IT nation within five years.” By issuing this strategy, the Japanese government provided its holistic policy agenda for nationwide IT use for the first time. In particular, the e-Japan Strategy shows four priority policy areas that the government should deal with:

- Establishment of an ultra high-speed network infrastructure and competition policies,

- Facilitation of electronic commerce,

- Realizing electronic government, and

- Nurturing high-quality human resources for the new era.

Among these policy areas, the section on electronic government declares the government's target to establish the electronic government by FY2003, by means of:

- Digitization of public administration within central and local governments, 
- Digitization of public services to the private sector,

- Publication and promotion of the use of administrative information via the Internet, and

- Support for local governments.

The e-Japan Priority Policy Program of March 29, 2001,12 shows further strategies toward an IT nation. This program adds "Ensuring of Security and Reliability over Advanced Information and Telecommunications Networks" to the priority policy areas. In this program, the chapter "Digitization of the Administration and Utilization of IT in Other Public Areas" explains recognition and priority policies for electronic government. The priority policies include electronic delivery of administrative information, electronic filing (application and notification procedures), promoting the use of electronic documents and eliminating paper-based documents, information sharing/use among administrative organizations through information networks, and provision of administrative services through information networks. In November 2001, the IT Strategy Headquarters issued the Acceleration and Advancement of e-Japan Priority Policy Program and e-Japan 2002 Program, ${ }^{13}$ which shows the schedules of each ministry's projects toward realization of e-Japan.

IT policy pages on the Website of the Japanese prime minister and his cabinet ${ }^{14}$ will provide further policy strategies and resources toward the development of electronic government and the information society in Japan.

\section{4. e-Gov.go.jp: A Platform for One-Stop Government Information and Services}

The result of policy instruments concerning electronic provision of administrative 
information, discussed so far, is e-Gov.go.jp, or the General Gateway System for Electronic Government. ${ }^{15}$ This Website is recognized as a one-stop platform for administrative information and services, and is expected to become the core of electronic government in Japan in the future. e-Gov was launched on April 1, 2001, the same day the IDL came into effect. It is managed by the Administrative Management Bureau of the Ministry of Public Management, Home Affairs, Posts and Telecommunications.

As of July 2002, e-Gov.go.jp consists of these functions:

(1) Retrieval system for contents of Japanese government Websites.

(2) Retrieval system for administrative procedures and forms.

(3) Retrieval system for administrative record files, mentioned as guidelines concerning record management (see 2.2.4.)

(4) Clearing system for Japanese government information: This is a locator service for government information in both electronic and paper formats. This function is the result of the "administrative information clearing system" mentioned by the original "Master Plan for Promoting Government-Wide Use of Information Technology" in 1994 and "an integrated locator system" described by the revised "Master Plan" in 1997.

(5) Links to cross-ministerial databases, including those for Japanese law texts and for procurement information.

(6) Links to databases of individual ministries, including the Industrial Property Digital Library, the GIS clearing house, and the Pollutant Release and Transfer Register Database, to name a few.

(7) Links to the Websites of each ministry: Categorized by ministry name as well as 
category of the site contents, such as description of organizations, press releases, administrative plans and projects, research reports, white papers, etc.

Among them, an English interface is available for only category (1). ${ }^{16}$

\subsection{Review of Policy Initiatives}

As discussed above, several policy initiatives in Japan have promoted access to government information and the development of electronic government. These policy initiatives are divided into five areas: promotion of IT use in internal administrative activities, the Information Disclosure Law, information provision, record management, and general policy toward information society. Table 2 shows these initiatives since 1994. The year 1994 marked the landmark for the development of electronic government. In this year, the establishment of the ARC paved the way toward the enactment of the IDL. Also, the original "Master Plan for Promoting Government-Wide Use of Information Technology" was established as the very beginning point of electronic government, and this plan was incorporated into the Basic Plan toward Promotion of Advanced Information and Telecommunication Society in the next year. After that, the IDL enactment of 1999 significantly impacted the improvement of government information provision. Finally, the issues of government information provision and an advanced vision for electronic government were incorporated into e-Japan policy initiatives.

[Table 2 about here.] 


\section{Discussion}

This section analyzes these policy initiatives and points out problems for the improvement of administrative information provision and the realization of electronic government in Japan.

\subsection{Treatment of Government Information}

First of all, the Japanese government has a huge problem in regards to the nature and treatment of government information itself. Certainly, government information provision has been improved significantly compared to the situation in the pre-Internet era. Still, there are several barriers for access to government information in Japan.

The Copyright Law of Japan allows the government to hold copyrights for its "works". ${ }^{17}$ Article 13 of the Copyright Law (Law No. 48 of 1970) excludes copyright protection from: (i) laws and regulations, (ii) notifications, instructions, circular notices, and the like issued by public entities, (iii) judgments, decisions, orders, and decrees of law courts, and (iv) translations and compilations of (i)-(iii) made by public entities. Therefore, other government "works" such as white papers, annual reports, handbooks, and Webpages can be copyrighted. Of course, there are a number of limitations to the copyright of such government "works", including reproduction for private use or in educational institutions and public libraries. Still, copyright protection for government "works" prevent full use of government information for citizens, as well as for information industries who wish to republish and/or repackage government "works" for 
a profit. In addition, Article 2 of the National Property Law (Law No. 73 of 1948) includes copyrights, patents, and trademarks held by the central government as "national property" managed strictly by the central government.

In this sense, a "state-sponsored monopoly over public information" is allowed in Japan, and this "state-sponsored monopoly" prevents Japanese society from establishment of a true "rule of law" nation. This is because the understanding of law among the public is necessary for a "rule of law," and multiple sources of government information, including redistributions for profit, facilitate this understanding. Such multiple sources also avoid censorship and information abuse by the government. ${ }^{18}$ While the United Kingdom government considered revision of the "Crown Copyright" for government works with the enactment of the Freedom of Information Act in November 2000, 19 discussions about government copyright seldom occur in Japan.

Another problem is the control of the flow and storage of government information. As Ginsburg argues, "In Japan, information flows easily and informally among those within the policy circles, but is unavailable to those outside of the circles." He discusses that those outside the policy circles still have difficulties in gaining access to administrative information they need despite the enactment of the Administrative Procedure Law and the IDL. ${ }^{20}$ In addition, as discussed below, implementation of the clearing system for Japanese government information has been disappointing so far. Also, management and preservation of government information/records have been given the very least priority in administrative activities. The enactment of the IDL urges improvement in records management and preservation, though there are numerous problems with this issue. For example, the Basic Plan for Electronic Provision of Administrative Information in March 2001 provides a retention period for each category 
of administrative information on the Web (see Table 1), but this plan says nothing about the treatment of administrative information whose retention period is over. Currently, no laws or statutes ensure preservation and permanent public access to administrative information on the Web.

So far, the Japanese government does not recognize that the usefulness of government information depends on proper treatment of government information, including omission of government copyright and control of the flow and storage of government information. As a result, the Japanese government fails to bring out the true potential of government information, which "plays a fundamental role in the proper functioning of the internal market and the free circulation of goods, services and people" for the European Commission, ${ }^{21}$ and is described as "a strategic national asset" by the United States. ${ }^{22}$

\subsection{Lack of Leadership and Coordination}

As shown in Table 2, policy initiatives toward electronic government are divided into five areas. However, there is a lack of strong leadership to implement the policies of each area, and a lack of coordination among these areas.

In general policy toward an information society, the IT Strategy Headquarters is responsible for the e-Japan strategy, and they mandate each ministry to accomplish policy goals shown in "IT-Related Policy Area of the Structural Reform Schedule," listed in the Acceleration and Advancement of e-Japan Priority Policy Program and the e-Japan 2002 Program in November 2001 (see 2.3). However, it is not clear how the IT Strategy Headquarters will ensure their accomplishment by means of evaluation of 
performance results and follow-up initiatives. On the other hand, the Administrative Management Bureau (AMB) of the Ministry of Public Management, Home Affairs, Posts and Telecommunications ${ }^{23}$ takes primary responsibility for the IDL and information provision issues, though the AMB suffers from the same drawbacks as IT Strategy Headquarters. (The AMB is similar to the function of the Office of Management and Budget in the United States, though the AMB lacks authority in budgeting.)

In regards to coordination, the Inter-Ministerial Council for Promoting Government-Wide Use of Information Technology (mentioned in 2.2.3), led by the head of the AMB, takes main responsibility to promote inter-ministerial coordination toward the development of an electronic government. This council was established on March 26, 2001, through the merging of the Inter-Ministerial Council for Internal Business and the Inter-Ministerial Council for Administrative Information System (both are mentioned in 2.2.4). Yet this council only facilitates each ministry to share its own situation and experience, but lacks valid authority to implement policy initiatives.

This lack of leadership and coordination leads to poor implementation of policy initiatives concerning information provision. For example, the government planned in the revised "Master Plan for Promoting Government-Wide Use of Information Technology" in 1997 that administrative information locator systems (clearing systems) would be operative in all ministries and agencies by the end of FY 1999, i.e., March 2000. However, even in July 2002, a very limited number of ministries provide data for the clearing system on e-Gov.go.jp. Worse, the Ministry of Public Management, Home Affairs, Posts and Telecommunications, the administrator of e-Gov.go.jp, does not provide their data for the clearing system! 
Access to Government Information in Japan

3.3. Policy Initiatives toward Electronic Government as A Part of Administrative Reform

It should be noted that policy initiatives toward electronic government in Japan are largely the result of administrative reform; remember that the enactment of the IDL was a part of administrative reform led by the Administrative Reform Council. Also, improvement of government information provision was inaugurated in 1994 by the "Master Plan for Promoting Government-Wide Use of Information Technology," as part of the internal administrative activities reform through the use of information technology.

The problem, however, is that the administrative staff themselves have been the leaders of policy initiatives toward electronic government as well as administrative reform. ${ }^{24}$ Certainly, there are a number of measures in place to accept opinions from outside the government in the policy-making process, such as input from legislators, deliberative councils, and public comments. However, in most cases, the origin and process of policy making are controlled by administrative staff, frequently supported by the opinions of the industrial sector. As Ginsburg points out, the Administrative Procedure Law of 1995 has no provisions for a policy-making process: "bureaucrats would see little need in a set of judicially-enforced rules governing the policy-making process." 25 The result is that policy initiatives as an output of the policy-making process allow a large amount of administrative discretion. In this sense, policy initiatives toward information provision and electronic government are weak in responding to needs outside the administrative body and incorporating focus of citizens.

Also, policy initiatives toward administrative reform and electronic government 
tend to focus on development of information systems and infrastructure, in part because the government was slow to recognize the significance of the Internet. In fact, the "Basic Plan toward Promotion of Advanced Information and Telecommunication Society" of 1995 mentions the word "Internet" only twice. Recent policy initiatives of e-Japan and government information provision try to take advantage of Internet technology, though they lack interest in empowerment of citizens and non-profit sectors using the Internet.

\section{Recommendations}

Supported by the development of information technology, the Japanese government has started opening up its information and taking steps toward electronic government. However, the policy initiatives do not reflect the needs of the citizen, and implementation of the policy is curtailed by the lack of leadership and coordination. In addition, the government still holds a monopoly over its information and has poor control over flow and storage of government information. In order to accomplish the first, "cataloguing" step of electronic government firmly, and to proceed to higher steps of electronic government, i.e. transaction, and vertical and horizontal integration, the Japanese government needs to take the measures below.

(1) Legal issues: Copyrights on government "works" should be restricted widely, so that government information can be freely reused and republished. Simplified licensing procedures for core government "works" and/or waiver of copyrights from these "works", which is being implemented in the United Kingdom, ${ }^{26}$ might be an option. Also, much more legislation on the issues of record management and permanent public access to 
government information is needed.

(2) Policy implementation and management: As Layne and Lee discuss, organizational challenges are not very significant in the "cataloguing" stage of electronic government compared with challenges in other stages: transaction, vertical integration and horizontal integration. ${ }^{27}$ Focusing on "cataloguing" issues, the Japanese government may not need to consider drastic organizational changes. Still, it is necessary for the government to establish strong leadership in order to implement information provision policies effectively and to prepare for the advanced stages of electronic government. The top management (e.g. the Cabinet) needs to give stronger authority for clear responsibility, performance measurements and follow-up during implementation of information provision policies. In addition, it may be necessary to make partnerships with industrial or non-governmental sectors for some areas, i.e. electronic system development and security, with which these sectors have more valid expertise than the government.

(3) Evaluation of policy initiatives: Another issue for effective implementation of the policy is evaluation. For a long time, the Japanese government rarely provided policy plans with measures for retrospective evaluations, and the policies concerning IT use for administrative activities and administrative information provision has been no exception. The Japanese government should establish service standards with quantitative targets, evaluate the performance of each administrative activity based on them, and conduct follow-up measures for those lagging behind them. As for IT investment, new standards for budgeting, accounting and auditing are needed. In addition, it is necessary to develop evaluation measures for Websites from the perspective of contents, design, usability, and so forth. ${ }^{28}$ Finally, the government needs 
to incorporate opinions of citizens and businesses when the government develop the standards and conduct evaluations.

\section{Conclusion}

This article seems to discuss a very limited area in electronic government, since the Japanese government as well as other countries have policy plans toward more interactive involvement among the government, citizens and businesses under the name of "electronic government", not limited to provision of government information. Also, this article does not discuss several serious challenges for the realization of electronic government, such as privacy, security, and human capital. However, enhancement of providing government information in an electronic environment is essential for the future development of electronic government. This enhancement could potentially create a more robust "rule of law" supported by "informed citizens," and more business chances for information industries, which add value to electronic government information. 
Table 1: Standardized Categories of Information that Shall be Provided through Japanese Government Websites

\begin{tabular}{|c|c|c|c|}
\hline Classification of Information & Category of Information & Example of contents & $\begin{array}{l}\text { Retention period for } \\
\text { information provision } \\
\text { on the Web }\end{array}$ \\
\hline \multirow[t]{2}{*}{$\begin{array}{l}\text { Basic information about } \\
\text { administrative organization } \\
\text { and system }\end{array}$} & & $\begin{array}{l}\text { Brief description of } \\
\text { administrative } \\
\text { activities; internal } \\
\text { organizations and } \\
\text { their activities; } \\
\text { directory of senior } \\
\text { management staff; } \\
\text { directions to the } \\
\text { offices; list of } \\
\text { extragovernmental } \\
\text { organizations }\end{array}$ & $\mathrm{N} / \mathrm{A}$ \\
\hline & $\begin{array}{l}\text { Laws, notifications, } \\
\text { instructions, circular } \\
\text { notices }\end{array}$ & $\begin{array}{l}\text { Text and summaries } \\
\text { of new and revised } \\
\text { laws; text of laws, } \\
\text { notices and } \\
\text { circulars of the } \\
\text { concerned ministry }\end{array}$ & $\begin{array}{l}\text { For the text of new } \\
\text { and revised laws- } \\
\text { until the time when } \\
\text { other government } \\
\text { databases provide } \\
\text { the same texts }\end{array}$ \\
\hline \multirow[t]{3}{*}{$\begin{array}{l}\text { Information on current } \\
\text { status of administrative } \\
\text { activities }\end{array}$} & $\begin{array}{l}\text { Master plans, projects, } \\
\text { etc. }\end{array}$ & $\begin{array}{l}\text { Full text or summary } \\
\text { of master plans, } \\
\text { projects, etc.; their } \\
\text { current status; their } \\
\text { results and costs }\end{array}$ & $\begin{array}{l}\text { Until the end or } \\
\text { revision of the master } \\
\text { plans, projects, etc. }\end{array}$ \\
\hline & Results of research & $\begin{array}{l}\text { Summary; reports; } \\
\text { related materials }\end{array}$ & Three years \\
\hline & $\begin{array}{l}\text { Materials of Shingikai } \\
\text { (deliberative councils) }\end{array}$ & $\begin{array}{l}\text { Full text and } \\
\text { summary of reports; } \\
\text { summary or full text } \\
\text { of the minutes; }\end{array}$ & Three years \\
\hline
\end{tabular}




\begin{tabular}{|c|c|c|c|}
\hline & & related materials & \\
\hline & Public comments & & $\mathrm{N} / \mathrm{A}$ \\
\hline & $\begin{array}{l}\text { Summary of white } \\
\text { papers }\end{array}$ & & Three years \\
\hline & $\begin{array}{l}\text { Briefing and summary of } \\
\text { statistical research }\end{array}$ & & $\begin{array}{l}\text { Until the publication } \\
\text { of new research }\end{array}$ \\
\hline & Procedures and forms & $\begin{array}{l}\text { Summary and } \\
\text { instructions for the } \\
\text { procedures and } \\
\text { forms }\end{array}$ & $\mathrm{N} / \mathrm{A}$ \\
\hline & $\begin{array}{l}\text { Procurement } \\
\text { information }\end{array}$ & & $\mathrm{N} / \mathrm{A}$ \\
\hline $\begin{array}{l}\text { Budget and account } \\
\text { settlement information }\end{array}$ & $\begin{array}{l}\text { Summary of the budget } \\
\text { and account settlement }\end{array}$ & & Three years \\
\hline Evaluation information & $\begin{array}{l}\text { Summary and full text of } \\
\text { policy evaluation and } \\
\text { audit }\end{array}$ & & Three years \\
\hline $\begin{array}{l}\text { Common to above } \\
\text { classification }\end{array}$ & Press releases & & Six months \\
\hline
\end{tabular}

Source: "Basic Plan for Electronic Provision of Administrative Information," approved by Inter-ministerial Council for Promoting Government-Wide Use of Information Technology on March 29, 2001. Tentative interpretation by the author. 
Table 2: Policy Initiatives Concerning Access to Government Information and the Development of Electronic Government in Japan

\begin{tabular}{|c|c|c|c|c|c|}
\hline Year & $\begin{array}{l}\text { Promotion of IT use } \\
\text { in internal } \\
\text { administrative } \\
\text { activities }\end{array}$ & $\begin{array}{l}\text { Information Disclosure } \\
\text { Law (IDL) }\end{array}$ & $\begin{array}{l}\text { Information } \\
\text { provision }\end{array}$ & $\begin{array}{l}\text { Record } \\
\text { management }\end{array}$ & $\begin{array}{l}\text { General policy toward } \\
\text { information society }\end{array}$ \\
\hline 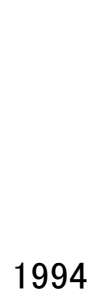 & $\begin{array}{l}\text { (Original) Master } \\
\text { Plan for Promoting } \\
\text { Government-Wide } \\
\text { Use of Information } \\
\text { Technology }\end{array}$ & $\begin{array}{l}\text { Administrative Reform } \\
\text { Committee (ARC) }\end{array}$ & & & $\begin{array}{l}\text { Advanced Information and } \\
\text { Telecommunication } \\
\text { Society Promotion } \\
\text { Headquarters }\end{array}$ \\
\hline 1995 & & $\begin{array}{l}\text { Administrative } \\
\text { Information Disclosure } \\
\text { Subcommittee of the } \\
\text { ARC }\end{array}$ & & & $\begin{array}{l}\text { Basic Plan for Promotion } \\
\text { of Advanced Information } \\
\text { and a Telecommunication } \\
\text { Society }\end{array}$ \\
\hline 1996 & & $\begin{array}{l}\text { Proposed IDL from the } \\
\text { ARC }\end{array}$ & & & \\
\hline 1997 & & & $\begin{array}{l}\text { Revised Master } \\
\text { Plan for } \\
\text { Promoting } \\
\text { Government-Wide } \\
\text { Use of } \\
\text { Information } \\
\text { Technology }\end{array}$ & & \\
\hline 1998 & & IDL bill & & & \\
\hline 1999 & & \multicolumn{3}{|c|}{ IDL Enactment } & \\
\hline 2000 & & & & $\begin{array}{l}\text { Cabinet order, } \\
\text { guidelines, and } \\
\text { memorandum } \\
\text { concerning } \\
\text { record } \\
\text { management }\end{array}$ & $\begin{array}{l}\text { IT Strategy Headquarters; } \\
\text { Basic Law on the } \\
\text { Formation of an } \\
\text { Advanced Information and } \\
\text { Telecommunications } \\
\text { Network Society }\end{array}$ \\
\hline 2001 & & IDL in effect & $\begin{array}{l}\text { Basic Plan for } \\
\text { Electronic } \\
\text { Provision of } \\
\text { Administrative } \\
\text { Information; } \\
\text { launching of } \\
\text { e-Gov.go.jp }\end{array}$ & & e-Japan Strategy \\
\hline
\end{tabular}




\section{Notes}

${ }^{1}$ David McClure, Electronic Government: Challenges Must Be Addressed with Effective Leadership and Management (GAO-01-959T) (Washington: U.S. Government

Accounting Office, 2001), 1. Available:

http://www.access.gpo.gov/su_docs/aces/aces160.shtml (June 19, 2002)

2 Karen Layne and Jungwoo Lee, "Developing Fully Functional E-Government: A Four

Stage Model," Government Information Quarterly, 18.2 (2001): 122-136.

${ }^{3}$ One of the unique initiatives for electronic government in Japanese local governments is discussed in: Christopher S. Thompson, "Enlisting On-line Residents: Expanding the Boundaries of E-Government in a Japanese Rural Township," Government Information Quarterly, 19.2 (2002): 173-187.

${ }^{4}$ Only the revised "Master Plan" of 1997 is available in English.

http://www.soumu.go.jp/gyoukan/kanri/b_01e.htm (June 19, 2002)

${ }^{5}$ For more details about the process toward the enactment of the IDL, see, for example: David Boling, "Access to Government-Held Information in Japan: Citizens' "Right to

Know" Bows to the Bureaucracy," Stanford Journal of International Law, 34 (1998): 12-23; David Moses Schultz, "Japan's Information Disclosure Law: Why a Law Full of Loopholes Is Better than No Law at All," Law in Japan, 27 (2001): 129-147.

${ }^{6}$ For more details about the Administration Procedure Law, see, e.g., Ken Duck, "Now That the Fog Has Lifted: The Impact of Japan's Administrative Procedures Law on the Regulations of Industry and Market Governance," Fordham International Law Journal, 19 (1996): 1686-1763; Lorenz Ködderitzsch, Japan's New Administrative Procedure Law: Reasons for Its Enactment and Likely Implications," Law in Japan, 24 (1991): 105-137. An English translation of the law is available at: "Administrative Procedure Act," translated and annotated by Mark A. Levin, Law in Japan, 25 (1995): 141-159. ${ }^{7}$ For an English translation of the IDL, see, Law Concerning Access to Information Held by Administrative Organs [translated for the Management and Coordination Agency]. Available: http://www.soumu.go.jp/gyoukan/kanri/translation3.htm (June 19, 2002). See Also, Main Points of the Law Concerning Access to Information Held by Administrative Organs; English translation. Available:

http://www.soumu.go.jp/gyoukan/kanri/mainpoint1.htm (June 19, 2002); Mechanism of Information Disclosure System. Available:

http://www.soumu.go.jp/english/gyoukan/img/002.gif (June 19, 2002)

8 For more details about the criticism to the IDL, see Schultz, op. cit., 147-167.

9 Citation from Main Points of the Law Concerning Access to Information Held by Administrative Organs, op. cit.

${ }^{10}$ Available: http://www.kantei.go.jp/foreign/it/it_basiclaw/it_basiclaw.html (June 19, 2002)

11 e-Japan Strategy. IT Strategy Headquarters, January 22, 2001. Available:

http://www.kantei.go.jp/foreign/it/network/0122full_e.html (June 19, 2002)

12 e-Japan Priority Policy Program. March 29, 2001. Available:

http://www.kantei.go.jp/foreign/it/network/priority-all/index.html (June 19, 2002)

13 Acceleration and Advancement of e-Japan Priority Policy Program and e-Japan 2002 Program. November 2001. Available:

http://www.kantei.go.jp/foreign/it/network/0204accelerate_e.html (June 19, 2002) 
14 Available: http://www.kantei.go.jp/foreign/it_e.html (June 19, 2002)

15 Available: http://www.e-gov.go.jp/ (June 19, 2002)

${ }_{16}$ Available: http://clearing.e-gov.go.jp/cgi-bin/HpSchSearch.cgi?LANG=1 (June 19, 2002)

${ }^{17}$ For more details about copyright protection over government "works" in Japan, see Tsutomu Kuroki, An Introduction to Japanese Government Publications (Oxford: Pergamon, 1981): 72-81.

18 Henry H. Perritt, Jr. "Open Government," Government Information Quarterly, 14.4 (1997): 399-402.

19 Reviews of Crown Copyright and Government Information (London, Her Majesty's Stationery Office). Available: http://www.hmso.gov.uk/pquest/review.htm (June 19, 2002)

20 Tom Ginsburg, "Dismantling the Developing State? Administrative Procedure Reform in Japan and Korea," Paper presented at the colloquium: The Multiple Worlds of Japanese Law: Disjunctions and Conjunctions (Victoria, Canada: Centre for Asia-Pacific Initiative Colloquium, April 3, 2001), 24. Available:

http://www.capi.uvic.ca/jplawconf/tomrepwk.pdf (June 19, 2002)

${ }^{21}$ Green Paper on Public Sector Information in the Information Society (Luxembourg: European Commission, adopted on January 20, 1999). Available: http://europa.eu.int/ISPO/docs/policy/docs/COM(98)585/ (June 19, 2002) Citation from "Introduction: The issue."

${ }_{22}$ A Comprehensive Assessment of Public Information Dissemination, Final Report, Volume 1 (Washington, U.S. National Commission on Libraries and Information Science, January 26, 2001). Available: http://www.nclis.gov/govt/assess/assess.vol1.pdf (June 19, 2002)

23 This ministry was established on January 6 , 2001, from the merging of three organizations: the Management and Coordination Agency, the Ministry of Home Affairs, and the Ministry of Posts and Telecommunications. Before this merging, the AMB had been located within the Management and Coordination Agency.

${ }^{24}$ For more details about policy-making problems in Japan, see Ginsburg, op. cit.

25 Ibid., 23.

${ }^{26}$ Click-Use Licence (London, Her Majesty's Stationery Office). Available:

http://www.hmso.gov.uk/click-use-home.htm (June 19, 2002)

${ }^{27}$ Layne and Lee, op. cit., 127.

28 For an example of evaluation measures for government Websites, see: Charles R.

McClure, J. Timothy Sprehe and Kristen Eschenfelder, Performance Measures for Agency

Websites: Final Reports (Washington, U.S. Government Printing Office, 2000).

Available: http://fedbbs.access.gpo.gov/libs/measures.htm (June 19, 2002) 